\title{
Entertainment Landscape and Ethnographic Shows in Gdańsk, 1860-1914
}

\author{
Dagnosław Demski \\ Institute of Archaeology and Ethnology, \\ Polish Academy of Sciences, Warsaw
}

\begin{abstract}
Ethnographic shows existed as peculiar projects in a specific time and space. Correspondingly, entertainment played a specific role in the life of modernizing cities. This article aims at reconstructing the circumstances and places of entertainment in Gdańsk, where representatives of 'exotic' peoples from distant continents performed on stage. The stage was not only that of ethnic shows (Völkerschauen), where the program of the performance was entirely devoted to one group, but also circuses, where 'exotic others' performed alongside other artists, as well as theaters with a light repertoire of variétés that were operating in Gdańsk at the time. The specificity of shows performed by people from distant lands seemed to reside in emphasizing differences: cultural, ethnic and civilizational. Questions emerge concerning what these shows were like, how 'wildness' was perceived and how 'exotic' daily life was presented? The presented materials have been gathered from the accounts and press advertisements of the Gdańsk press at the time. If meaning in shows was embodied in form, technique, and place, the question at hand, is what precisely we can ascertain about entertainment institutions in urban landscape from this kind of data.
\end{abstract}

Keywords: contact zone, ethnic shows, Gdańsk/Danzig, modern city, summer theatres, urban landscape

\footnotetext{
"The passion for close visual observation on the spot had transformed how landscapes were experienced and described during the eighteenth century and shaped how specimens brought into galleries were exhibited, to the point that the experience of travel became the model of exhibitions about other places. Visitors were offered the display as a surrogate for travel, and displays in turn participated in the discourse of travel" (KirSCHENBLATT-GimbletT 1998:43).
}

Gdańsk (German: Danzig) is a special city on the map of Europe. This is due to its geographic location on the Baltic coast, on land inhabited by German and Slavic peoples. In terms of the historical precedents of the city, Gdańsk was part of the Hanseatic League 
from 1371 until the $17^{\text {th }}$ century. During the period after 1793 , the city belonged to the Kingdom of Prussia. Between the years 1871-1918, Gdańsk was part of the German Empire, constituting the eastern frontier of Germany. From 1920-1939, it was known to be the Free City of Gdańsk. The city has been under Polish rule since 1945. In terms of the economic and commercial role of the city, Gdańsk served as a port at the mouth of the Vistula River, where floating goods, international trade, and merchant fleet were common. Gdańsk was privy to special residents from the Hanseatic times onwards, boasting a rich and strong bourgeoisie class.

These factors contributed to the fact the city was an important port during the years discussed (1860-1918). It was a rich, vibrant, industrial, commercial and cultural center that was part of the Prussian state, and German civilization, with a predominant German population. ${ }^{1}$ Gdańsk was an example of one of the many large Prussian cities that had significant cultural and regional centers. A highly cultural scene developed as well as popular entertainment for mass culture. Both are worthy of a separate study. The diversity of the city is evidenced by its architecture, the wealthy city center as well as the less sophisticated districts that surround it.

During the last decades of the $19^{\text {th }}$ century, cities of Central Europe experienced a process of modernization, following the footsteps of Western Europe. Gdańsk became a city with many possibilities. The urban lifestyle developed slowly. New forms of popular events existed. They were included within the dynamics of mass modern entertainment; namely through itinerant museums of wonders, cafés, cinemas, panopticons, Kaiser panoramas, cabarets and variety shows, as well as fair attractions like shows of 'exotic' ethnic peoples. The shows and performances took place in specific places and for the purpose of this article I call them 'places of encounter with the other'. Places change their character, but often times their specificity or locations in the city retain some inherent features that remain despite changes. The best example of this is the St. Dominic's Fair, with its long tradition, ludic specificity, and how it was associated with places around the walls of the Old Town in the past. I will also point out other places that were linked to a specific type of entertainment and with the presence of 'exotic' characters. Is it possible then, to distinguish city spaces that make up the stage for specific events - zones of secular and sacred power, port, industrial and residential districts, as well as zones of light entertainment? Each city has its own history, thus, it is difficult to look for universal principles. I will discuss this issue in the context of Gdańsk and I will try to provide an answer to this vital question.

The central aim of this paper ${ }^{2}$ then, is to introduce readers to demonstrations of 'exotic' peoples in Gdańsk from 1860 until the outbreak of World War I. During this period in Germany, a new model of staging 'exotic' people emerged which was initiated by Carl Hagenbeck in 1874. As we will see, these types of performances also arrived in Gdańsk, albeit less often than in other German cities. I focus on the years 1860-1918 and document all the shows in which 'exotic' actors took part. I also quote previous performances. Nevertheless, my main point is to compare the presentations of 'exotic' people - which took place in the researched period and followed the model of

\footnotetext{
1 On the history of Gdańsk, please see CIEŚLAK 1969-1997 (vol. 1-5).

2 The National Science Center project Opus 10 served as the incentive for this article (UMO2015/19/B/HS3/02143).
} 
Hagenbeck's caravans - with those that took place in small theatrical gardens as well as the variété scenes of Gdańsk. I perceive both types of performances as manifestations of the modernization process (GIDDENS 2002; 2003; 2008).

This phenomenon belongs to the forms of entertainment in which curiosities and attractions come to the fore. ${ }^{3}$ One of my points is to reconstruct a map of places in the city and the local background in which 'exotic' people from distant continents were displayed in front of the public. According to Edward Casey, "places ... provide the scene for action and thought, feeling and expression" (CASEY 1996:38). In Gdańsk, the scene discussed here, consisted of both open and indoor spaces hosting various performances. Ethnic shows (Völkerschauen), where the program of the performance was entirely devoted to one ethnic group, were held for many years in places where the celebration of St. Dominic's Day took place - mainly squares around the Old Town walls: the Targ Drzewny (Timber Market), the Targ Węglowy (Coal Market), and areas around the Old Town gates, such as the Brama Oliwska (Oliwa Gate) and the Brama Żuławska (Żuławy Gate). Circuses, as well as theatres offered a variety of repertoire. The ethnic aspect was present in many performances at cafes that operated in Gdańsk at that time. Ethnic actors almost exclusively belonged to organized troupes, visiting the city on their way from Berlin to the east or on their way back to Berlin. The phenomenon of demonstrations of 'exotic' peoples was known in many towns now belonging to Poland under the German, Russian and Austrian partition. So far, the shows and their background in cities located on the territory of the current Polish state have been presented by a number of authors, e.g. Wrocław (CZARneCKa 2018), Opole (BARANIECKa-Olszewska in the present volume), Poznań (Demski 2018a; 2018b; 2020; KUReK - MAYer 2017), ${ }^{4}$ and in a wider geographical scope that extends beyond a single urban center (BARANIECKA-OLSZEWSKA 2020; CZARNecKa 2020).

Anthony Giddens observes that there was an acceleration of development in the modern era; while changes that took place reached an unprecedented extent (GIDDENS 2002:23). These changes had a radical impact on existing practices and social behaviors. The inhabitants of many industrialized and expanding cities, including Central European towns and cities, were growing aware of the presence of distant 'others.' Both spatial and temporal distances were associated with imaginations of exoticism, and this, in turn, was reflected in the representations of 'primitive' cultures. This is of additional significance in the case of Gdańsk and all other German cities, due to the fact that Germany was one of the European colonial powers. As we know from history, colonial expansion on several continents (1884-1918) was interrupted after the defeat of Germany as a result of World War I. ${ }^{5}$ The period discussed here, was a time of the integration of Gdańsk into the world not only by sea, but also by land through links with railway lines connecting Berlin and other cities of Prussia.

\footnotetext{
3 Lukasz Biskupski writes about Łódź, combining the history of cinema with commercial entertainment. He defines it as a culture of attraction (BISKUPSKI 2013:20).

4 Demski's articles are based on both Polish and German language press materials, while Kurek and Mayer review only the Polish-language press titles in Poznań.

5 For more on this topic, see DEMSKI 2018.
} 
In drawing on German-language press ${ }^{6}$, I analyze ways of presenting 'exotic' others and their reception by local audiences. Not having many materials on the reception of these shows by the residents of the city, I decided that these types of shows will be discussed with reference to the venues. I will present the spatial dimensions of a specific kind of cultural practice. Such an approach to the analysis of shows that have a light entertainment nature can offer some insights, perhaps not apparent otherwise.

I use the term 'landscape' in the title, which refers to not only an area or the grounds, but also to practices and representations of the land. I am interested in the relationship between people and the environment, in this case, the city (TUAN 1987); the area of influence of certain rights resulting from the area inhabited by people, and their certain way of being. Landscape is marked by history (HASTRUP 1998); thus, one can try to capture the knowledge of the times in the joint experience of space (INGOLD 1993), exhibited by residents participating in ethnic shows located in well-known places.

The various types of shows presented here are treated as practices. Space has no meaning apart from practice; thus, I treat it as a socially constructed place. Therefore, the sense of place is the starting point of this study of the city. My incentive is to look at Gdańsk through the lens of the inhabitants of the second half of the $19^{\text {th }}$ and the beginning of the $20^{\text {th }}$ centuries. This is the period of the city's development, visible on many levels, connecting it with the world in terms of communication and new technologies; entering the age of modernity (CIEŚLAK 1998-1999:vol. 4). In this sense, I address the question of experiencing modernity, ${ }^{7}$ which encompasses the development of technology, the effects of the industrial revolution, as well as urbanization, the everyday life of the inhabitants of the erstwhile city, including new forms of entertainment. According to Hannu Salmi writing on the transformation of European cities of that period, the production of entertainment was linked to the city. Salmi mentions "literature, photography, painting, musicals, shows, travel reports and completely new forms of culture", such as the transformation of traveling to distant places into "tourism" (SALMI 2010:114). I focus on the culture of the city, or rather on the fragment devoted to entertainment.

Due to the wealth of events - for the purpose of this article - I will refrain from reflecting on concerts, parades and museums - forms of entertainment that were linked to high culture. Music pieces and museum objects might be perceived as closely related to the ideas of order, based on following the path of progress: freeing oneself from limitations and nature, achieving success in mastering the world through technique, perfecting perception and transforming distant spaces in terms of economy and political power.

However, there were institutions of a more entertaining nature than education, such as light theatres and variety shows which belonged to the category of the (new) entertainment of urban communities. Most often, these institutions had local roots and traditions; thus, reflecting ideas that were not always in tune with the industrial and urban sprawl of modernity. If the previous 'educational institutions', such as museums, were to strengthen the concept of a new order (the broadly understood spirit of modernization), then the goal of the latter was not ideology but rather simple entertainment deprived of other elements. During the second half of the $19^{\text {th }}$ century, it was in this world of cheap and

\footnotetext{
6 The majority of the Gdańsk press titles from the turn of the $20^{\text {th }}$ century are available at the library of the Polish Academy of Sciences in Gdańsk.

7 The term comes from Anthony Giddens (2003; 2008).
} 
light entertainment that performances featuring people from distant continents emerged (in a larger number and for wider audiences). Thus, a new world, new characters and representatives of distant places and cultures entered the spectrum which had previously been reserved for traditional forms of entertainment.

It seems that in both cases, although to a different degree, new types of events and new forms of spectacle created a sense of place for city dwellers, each in their own way. Consequently, these places, in connection to the form of performances, indicated their profound position in the new city landscape. In a sense, places where spectacles were shown show greater durability than concrete forms of entertainment. They constitute a part of urban space which consists of architecture, urban layout, division into quarters, etc. Simultaneously, there is a 'history' of what is inside and outside of locations. This history consists of two narrations and two stories. Does such an approach to the theme of spectacles with the participation of 'exotic' peoples result in insights regarding the issues of performances, entertainment at the turn of the $20^{\text {th }}$ century, and that of the urban landscape?

What can be said with certainty is the fact that these events and performances belong to a specific epoch, place and time, as well as to some kind of community and culture. They appear as one of the emanations of the values and visions of the community. They fall and go along with the transformation of this community through transformations of values, and changes in the wider context in which the community is embedded. My goal is to extract the form - included in the general category of ethnic entertainment shows focusing on the presentation of the 'exotic'; which was seemingly invisible, overlooked, not worthy of attention, but ever present in the city.

\section{SOURCES}

The materials on ethnic shows presented in this article mainly derive from the local press. ${ }^{8}$ Several press titles were issued in Gdańsk. Most are in German. Among others: Danziger Zeitung (1858-1930), ${ }^{9}$ Danziger Courier (1882-1901), Danziger Neueste Nachrichten (1894-1944), Danziger Dampfboot (1800-1888), Die Neue Wogen der Zeit (1849-1876), Danziger Volksstimme (1920-1936), and Gazeta Gdańska [The Danziger Gazette] (1891-1939) in Polish.

The Danziger Zeitung magazine was liberal; on two pages it included announcements advertising events in the city, including entertainments and attractions. The Danziger Neueste Nachrichten was a continuation of Danziger Courier which closed up in 1901. In both magazines, one can find plenty of advertising-promotional-illustrative material on entertainment. From the angle of entertainment, one can find more of this type of material there than in the Danziger Zeitung. The Danziger Dampfboot was humor oriented magazine. The magazine Danziger Volksstimme, founded in 1920, was populist and anti-

\footnotetext{
8 At this point, I would like to express my gratitude to Mr. Jerzy Michalak from Gdańsk - an expert on the history of the city; a person familiar with the archives and the old press - for his valuable advice and for pointing out materials about Gdańsk, as well as our numerous discussions. Without the possibility of discussing these issues with Mr. Michalak, this paper would look different. I owe him a debt of gratitude for much of the information about shows in Gdańsk.

9 The newspaper represented the liberal trend. The new authorities closed it in January of 1930.
} 
Semitic in character. The Gazeta Gdańska mainly dealt with Polish affairs. These last two newspapers appeared in the new era, thus, I will not dig deeper into their analysis. ${ }^{10}$

I will discuss two groups of shows. The first one includes ethnic shows (Völkerschauen) such as caravans that visited Gdańsk in the 1890s: Wakamba Neger Karawane (August 3-17, 1890), Suaheli Karawane (August 8 - September 11, 1893) and Neger Karawane (July 31-August 7, 1894). The shows listed here took place on the Plac Węglowy (Coal Market), i.e. in the previously discussed space around the Old Town. The second group is represented by entertainment productions offered in new types of venues of the modernizing city (such as variété scenes). Such a comparative approach will allow me to demonstrate that the diversity of the forms of entertainment and differences in the shows in which ethnic actors took part, indicate the existence of different models of presentations of peoples of distant cultures that require different space and a different public.

The main feature of performances is the fact that they are ephemeral. In the present day, we are fortunate to have ample recording techniques (film, photos, music, etc.). Resultantly, the reconstruction of the event does not cause any problems. However, at a time when the visual record did not exist outside the sphere of drawings or incidental photographs, the group's performance, spectacle or show, could only remain in memory, in more or less incidental notes in the press, memoirs, and municipal documents. Postcards mass-produced for the purpose of promoting these shows constitute a separate category of iconographic sources. Unfortunately, I did not succeed in finding any postcards representing scenes of ethnic shows in Gdańsk.

\section{GDAŃSK - THE CONTEXT AT THE TURN OF THE 20TH CENTURY}

Due to its location at the mouth of the Vistula River, historically, the city was connected with Poland. In contrast to Warsaw, Krakow and Vilnius, where kings, bishops, magnates and monasteries influenced the development of the city and architecture, Gdansk retained its bourgeois character. The population of the city located in the eastern borderlands of the German Empire identified with Germany. In a book published in Warsaw, Mieczysław Orłowicz writes that at the end of the 1920s, inhabitants of the Free City of Gdańsk "had a sense of grudge against Prussia, ungratefulness for loyalty to the Germans" (OrŁowicz 1928:45) or that "Gdańsk inhabitants are perfect Germans" (OreOwICZ 1928:45). Gdańsk had extensive fortifications (erected intermittently from 1343 to 1914, when the old walls were modernized for the last time, adapting them to new construction techniques.) The subsequent gates were erected along with the development of the fortification system: Brama Nizinna (Lowland Gate, 1626), Brama Żuławska (Żuławy Gate, 1628), Długich Ogrodów (Long Gardens) and Brama św. Jakuba (St. James' Gate, 1625-1635). The Prussians created a fortress, building modern forts around the city. The city was connected to the world by the sea, maritime economy, shipyards, fishing, and

${ }_{10}$ In both newspapers, there were announcements of the arrival of the Hagenbeck circus in 1930. Not many comments were issued, but it was mentioned in the Gazeta Gdanska that this performance evoked great interest. 
a great military port. ${ }^{11}$ In the second half of the $19^{\text {th }}$ century, numerous improvements were introduced, among others sewerage was built, ${ }^{12}$ and urban transport was developed.

The Old Town is surrounded by fields and wasteland from the sea, and separated from the city by the Brama Żuławska (Żuławy Gate). Traces of the past can be seen today, on the left there are pre-war low buildings, sand streets, Wygon (Pasture) and Mostek (Small Bridge), which point to the limits of the city.

The internal divisions of the city focused on the river and the port. If we walked through the city today, the preserved architecture reflects the old divisions. The oldest part was located on the banks of the Motława River. The right side of the river has expanded, transforming into the Old Town (nowadays Śródmieście), constituting the administrative, sacral, commercial and residential center of the city. This is evidenced by churches and former tenement houses. Residential districts grew in the towns of Wrzeszcz (Langfuhr) and Sopot (Zoppot). The left side of the Motława River was a district close to the actual city center, and at the same time (due to the limited space) it was a kind of suburb or side part of the Old Town. These parts differ in architecture; representative and rich on the left bank and less so, on the right bank of the Motława River. It is here that theatres with a lighter repertoire were established - close to the center and yet not in the very center.

From the point of view of locating the city in the network of transport within the network of Prussian cities, until the second half of the $19^{\text {th }}$ century, Gdańsk was a kind of a 'closed city'. As Mirosław Gliński writes, the first train arrived in Gdańsk on July 17, 1852, and it was a trial ride on the tracks from Tczew (Dirschau). On August the $5^{\text {th }}$, a single-track railway line between Gdańsk - Tczew was inaugurated. This was celebrated by the King of Prussia, Frederick William IV, who came to the Gdańsk ceremony from Bydgoszcz. It follows that this connection had a local character, and passengers from Gdańsk transferred in Tczew for long-distance trains (GLIŃSKI - KUKLIŃSKI 1998:156). It was close to Królewiec (Königsberg), and in opposite directions to Bydgoszcz and Torun. ${ }^{13}$

From 1857, when the construction of a road and rail bridge over the Vistula River in Tczew were completed, Gdańsk gained a direct railway connection with the rest of Prussia (with Malbork, Królewiec, and Elbląg ${ }^{14}$ ). This meant that Gdańsk was, for quite a long time, inaccessible by land and was located outside the extensive railway network of eastern Prussia (Silesia or Greater Poland).

In 1880, the Westpreußisches Provinzial Museum (a natural history and archaeology museum) in Gdańsk was opened and on this occasion, a meeting of naturalists and ethnologists took place (GLIŃSKI - KUKLIŃSKI 1998:70). In 1896, the first cinematographic

11 From 1865, it was the main military port of Prussia. It was only after the Germans captured Schleswig that it was transferred to Kiel (OrLOwICz 1928:51).

12 Gdańsk was the first completely sewered city (1869-1871) on the European continent (OrŁowicz 1928:50).

13 The railway station in Bydgoszcz was constructed in 1851, but due to the development of railway traffic, a new building was erected in 1870. In Torun, the railway station was built in 1861 and it was renovated in 1870 .

14 In 1870, a single-track railway line between Gdańsk and Sopot was started, which was operated by suburban trains. From 1873, Gdańsk had a direct convenient connection with Berlin (TczewChojnice-Piła-Berlin). In 1877, the connection between Malbork and Mława was initiated, and in this way, a railway connection with the territories of the Russian partition was obtained. In 1900, the main station in Gdańsk was put into operation (GLIŃSKI 1998:156). 
screening took place in the Wilhelm theatre hall (GLIŃSKI - KUKLIŃSKI 1998:181). The majority of Gdańsk residents were German; however, the city's industrialization process led to the influx of non-German people from nearby regions.

The Anthropological Society (Anthropologischen Vereine) ${ }^{15}$ organized foreign expeditions, regional trips, as well as anthropological and ethnographic exhibitions. ${ }^{16}$ The materials indicate that anthropology developed in Gdańsk. However, it seems that it did not have any special status in the city. Members of the Society adhered to current theories and practiced standard procedures linked to the instrumentalization of research, through trips, and exhibitions.

Advertisements in the Gdańsk press provided a lot of information from all around the world. For example, the 1904 issues relayed information on one of the largest exhibitions in the world; namely, the World Fair in St. Louis, where demonstrations of 'exotic' peoples were included. Moreover, another type of urban entertainment can be observed - tourism - the beginnings of which can be detected in advertisements in the 1890s. Trips were another possibility of outdoor entertainment. In 1905, Gdańsk travel agencies offered trips to Sicily, Tunisia, Algiers, Italy, Naples, Rome, Dalmatia, Corfu, and Venice (for example during the entire year of 1905 in the Danziger Zeitung).

\section{PLACES OF SHOWS}

Like many other large German cities, Gdańsk developed high and also popular culture for all inhabitants. Each of the venues offered diverse types of performances, their places on the city map differed, as well as the audience. As we shall see, caravans of 'exotic' peoples, circuses and theatrical performances with a light repertoire, were linked to specific places on the city map.

In this approach, emphasizing the diversity of entertainment and indicating its connections with specific places in Gdańsk, elements such as space and landscape are worth highlighting, in combination with a specific type of representation in which people of 'exotic' origin appeared or were presented as 'exotic'. I will demonstrate how space is associated with this type of repertoire. Moreover, I will describe it as a meeting place with the 'other' and the 'exotic'.

Tim Edenssor, in writing about contemporary tourism, distinguishes two types of tourism space: enclave and heterogeneous. The first is standardized and created for the needs of tourists, and the locals appear as services. The second is shared by locals and tourists, where they interact in addition to the roles assigned to them by tourist contact

15 The Society in Gdańsk was a local branch of the society founded on April 1, 1870 in Mainz (Deutsche Gesellschaft fuer Anthropologie, Ethnologie und Urgeschichte). The Society Statute was signed in 1870 by, among others, Rudolf Virchow, Alexander Ecker, Hermann Schaaffhausen, Carl Semper, and Joseph Vornberger.

16 The preserved brochure indicates that the trips were organized for members of the Society. For instance, travelling to Caucasus via Russia, to Scotland or to Hamburg to visit the Hagenbeck Zoological Garden (Stellingen Tierpark) Gdańsk, Archiwum Państwowe [State Archive], 7.561: Anthropologischer Verein zu Danzig und andere naturforschende Gesellschaften Vereine 18751892; 7.562: Anthropologischer Verein zu Danzig und andere naturforschende Gesellschaften Vereine $1892-1918$. 
(EDENSSOR 1998:41-68). Such a division can be applied to the entertainment space offering attractions. The character of the enclave was the stage space as a meeting place with the audience, and in the case of my considerations - meetings with ethnic 'others', where there was a rigid division between the performing 'exotic' actors and the audience. Heterogeneous space in the sense of outside stage interaction did not exist.

According to the ads and press coverage from the end of the $19^{\text {th }}$ century, the St. Dominic's Fair - the place of the annual holiday celebrated in the first week of August - is one of the greatest venues and attractions on the map of Gdańsk. Subsequently Nowe Ogrody 6 (New Gardens, Neugarten) - the seat of the Victoria Theatre (VictoriaTheater), Długie Ogrody 31 (Long Gardens, Langgarten), the seat of the Selonke's Variety Theatre, and later (from April 1877) the Wilhelm Theatre (actually WilhelmTheater), Tivoli Theatre (Tivoli-Theater) at Am Olivaer Tor 8 (currently: Gdyńskich Kosynierów Street).

As one can see, theatres were founded and staged in the city center and for years well communicated with the rest of the city. The Lower Town located near the city center with the town hall, cathedral, churches and tenement houses belonging to wealthy merchants was separated by a bridge over the Motława River. The extension of Długa (Long) Street - the main route of Gdańsk - was Długie Ogrody (Long Gardens) Street with low buildings and theatres. These two parts of the town offered different kinds of events and performances, at different times for visiting them, which appealed to different needs, tastes and concerns.

\section{ST. DOMINIC'S FAIR}

The most famous event in Gdańsk was (and still is) the St. Dominic's Fair. ${ }^{17}$ The attractiveness of the event results from the combination of a commercial offer (over 1.000 stalls with antiquities, antiques, artistic and hand-made products) with a rich cultural program. Its momentum is comparable with such well-known European events as Oktoberfest in Munich or Weinachtsmarkt in Hamburg and other German cities. St. Dominic's Fair was above all an entertainment and commercial event. In the $19^{\text {th }}$ century, the fair went beyond the urban embankments: to the Targ Sienny (Hay Market) with the surrounding areas and to the areas adjacent to the Brama Oliwska (Oliwa Gate). It took place successively in several venues: near the Brama Wyżynna (Highland Gate) - the Targ Węglowy (Coal Market) (trade and market stalls), the Targ Drzewny (Timber Market) - booths typical of a funfair. In the $19^{\text {th }}$ century, the fair also reached the Brama Żuławska (Żuławy Gate). The rows of stalls were set for the fair on the central reservation of the Długie Ogrody (Long Gardens) Street, later taken over by tramways. In 1875, circus tents were pitched, among others, at the Targ Sienny (Hay Market on the Radunia Canal). In the $20^{\text {th }}$ century, the fair grew towards the east. Many stalls also stood

17 The tradition of the St. Dominic's Fair dates back to 1260, when Pope Alexander IV allowed the Dominicans of Gdańsk to grant well-held indulgences on the day of their founder's feast. Nowadays St. Dominic's Fair is one of the biggest tourist attractions of the summer season in Gdańsk. About 6 million visitors visit it every year. This data was given on the website of the organizers of the Fair: http://jarmarkdominika.pl/wydarzenie/historia/ (accessed March 11, 2019). 
along the Motława river bank and in the Lower Town, to the left, near the Długie Ogrody (Long Gardens), in the neighborhood of the Most Siennicki (Siennicki Bridge).

At the August Fairs, over 400 ships with all kinds of goods arrived at the port of Gdańsk, including French and Spanish wines, silk, jams, spices, tin, English cloth, amber, Czech glass, Toruń gingerbread and Russian furs. Circus performers, acrobats, jugglers and actor troupes came from all over. The ceremonial opening of trade and fun was announced at noon by the Gdańsk bells. Initially, the Fair was held on the Plac Dominikański (Dominican Square), but it gradually moved to the vicinity of the Wały Jagiellońskie (Jagiellonian Embankments), Długa (Long) Street and new marketplaces, like Drzewny (Timber), Sienny (Hay), Węglowy (Coal), Wąchany (Sniffing), Rybny (Fish), whose names came from the goods they traded on. ${ }^{18}$

It was an open space. Thus, on St. Dominic's Day stalls and booths that provided the fairground entertainment were erected. Booths were also located south of the center of Nowa Motława on Szopy (Shacks) Street. The feast lasted two weeks. There was an abundance of amusements, presentations of inventions, such as balloons or airship Graf Zeppelin (1929), ${ }^{19}$ and shows of 'exotic' peoples from Africa. There were also theatrical performances, circus performances, pyrotechnic shows, and many others. The spectacles were played and shows were performed many times during the fair. Stalls and shacks offered the same types of goods.

During the St. Dominic's Fair in 1865, 'guests' - as advertised - from the desert of South Africa appeared at the Targ Wegglowy (Coal Market). ${ }^{20}$ Among them, was a woman from the bush (Das Buschweib Afandy) - a Bushman female named Afandy. This character is known from the history of shows in Europe. In later years, she performed in other German cities. ${ }^{21}$ A print showing the woman was presented in a book by Johannes Ranke published in 1923 (RANke 2017:57). ${ }^{22}$ Her show, due to the features of the body structure, could be included in the category of freak shows.

As reported by the press, on June 21 of 1886, performances of the Berber troupe took place in Gdańsk - twenty people of Beni-Zoug-Zoug from the Sahara Desert. ${ }^{23}$ The venue was not disclosed. A group ${ }^{24}$ forming high human pyramids used this name. The Berbers were presented as a group of acrobats, gymnasts, jumpers and athletes, presenting the show in the Arabic style. They also performed in England $(1867,1869)^{25}$ and in Italy (1883). ${ }^{26}$

18 Based on: https://www.gedanopedia.pl/gdansk/?title=JARMARK_\%C5\%9AW._DOMINIKA (accessed March 11, 2019).

19 https://www.gdansk.pl/historia/dominik-czyli-doroczny-targ,a,84364 (accessed March 11, 2019).

20 Danziger Zeitung, 1865 no 3147 (Aug 8):1; 1865 no 3160 (Aug 15):4; Danziger Dampfboot, 1865 no 181 (Aug 5):4; 1865 no 185 (Aug 10): 4; 1865 no 190 (Aug 16):2.

21 Anne Dreesbach mentions her show at the Charlottenburg Palace in 1866 (2005:32).

22 This photo comes from the collection: Die Eingeborenen Sudafrikas (FriTsCH 1872).

23 Danziger Dampfboot, 1866 no 2 (Jan 3):2; 1866 no 3 (Jan 4):4; 1866 no 5 (Jan 6):4; 1866 no 6 (Jan 8):2; 1866 no 7 (Jan 9):4; 1866 no 8 (Jan 10):4; 1866 no 9 (Jan 11):6; Danziger Zeitung, 1866 no 3397 (Jan 3); 1866 no 2400 (Jan 4)4; 1866 no 3402 (Jan 5):4; 1866 no 3404 (Jan 6):4; 1866 no 3406 (Jan 8):4; 1866 no 3408 (Jan 9):4; 1866 no 3410 (Jan 10):4; 1866 no 3412 (Jan 11):4

24 The name itself refers to the Berber tribe inhabiting the area of Chelif in Algeria.

25 See: Davis 2012:322.

$26 \mathrm{http} / / / w w w . i l$ ridotto.info/en/content/il-circo-dei-sogni-fra-acrobati-e-maghi-giganti-e-gorilla (accessed April 30, 2019). 
As a place and type of entertainment, the St. Dominic's Fair belonged to the previous era, the time of pre-modernization. As we can see, in the modernizing city, there were new editions of the events presented in the same places and in a similar form as in the old days, although sometimes filled with new content.

\section{THEATRES WITH A LIGHT REPERTOIRE}

Serving as a separate category were the variety theatres which gained popularity in the 1880 s. There were several of them, all located in the city center, nowadays we would say in the Lower Town, on the other side of the Motława River. Meetings with outsiders occurred on the stages of these cabarets and summer theatres and in the entertainment gardens. They were mostly actors, performing a play or a program, and sometimes there were shows in the repertoire whose titles foretold such kinds of meetings. At present, we do not always get to see if they were actors of 'exotic' origin or locals playing the role of 'exotic' characters.

The Victoria Theatre (Victoria-Theater) was located on the Nowe Ogrody (New Gardens) Street 6. The location was on the outskirts of the Old Town, but still within the city gates. It was opened on June 8 of $1886 .{ }^{27}$ From the beginning, it functioned as a summer entertainment theatre. The first director of the theatre was Julius Gottlieb Radike and the artistic direction was carried out by Ludwig Wöllfer. It was open from the first days of May to the end of September. The building housed around 500 spectators, in its parterre part there were tables where food was served. The plays were performed by local actors and singers, as well as artists from outside of Gdańsk. The repertoire was dominated by comedies, chamber operas, vaudevilles, and ballet performances. The theatre operated until September of 1870.

In the year of opening (1862), some of the guests at the St. Dominic's Fair were a troupe of artists lead by L. Söismann from Amsterdam and among them, next to the Dutch and English, Moroccans and Arabs were mentioned. ${ }^{28}$ As the press informed, the show itself took place in the Victoria theatre. Gymnasts were admired for their skills, although the countries of their origin added a bit of mystery.

As a supplement, I will add that the Japanese troupe was announced in May of $1866^{29}$ of having five shows at the city theatre in Gdańsk. Apart from the fact that they presented a classical repertoire, there is not much else I can add about it.

Demand for these types of summer theatre attractions remained. Mass commercial entertainmentfit well into the 'urban lifestyle'. Therefore, on the same street, at Langgarten 31 (Długie Ogrody, Long Gardens Street) a new Selonke theatre (Selonke's VariétéTheater) was established. It belonged to the same category of entertainment. Moreover,

\footnotetext{
27 Information on the basis of the entry in the online encyclopedia about Gdańsk. https://www. gedanopedia.pl/gdansk/?title=SELONKE $\%$ E2\%80\%99S_VARIET $\%$ C3\%89-THEATER (accessed March 11, 2019).

28 Danziger Zeitung, 1867 no 1457 (Aug 22):4; Die Neue Wogen der Zeit, 1862 no 93 (Aug 7):726; 1862 no 94 (Aug 9):733-734; 1862 no 95 (Aug 12):742-743; 1862 no 96 (Aug 14):750.

29 Danziger Dampfboot, 1868 no 120 (May 25):2; 1868 no 121 (May 26):4; 1868 no 124 (May 29):2; Danziger Zeitung, 1868 no 4857 (May 24):4; 1868 no 4858 (May 25):4.
} 
it had a light, popular program. It was founded by Franz J. Selonke. Performances began on November 1 of 1869. It was bigger than the previous site and consisted of a new wooden building with a stage and a summer garden for 2.000 consumer places as well as an outdoor stage.

The press reported that in 1869, a Chinese troupe appeared in the Selonke theatre (Vaudeville Theatre Selonke) ${ }^{30}$ - Sam-Ang, Arr-Zang and Frau a.G. I., advertised as genuine Chinese characters, appearing in original Chinese attire. There is no account of their performances, but based on the advertisements and announcements, the third person (Frau a.G. I.) must have been a person dressed in Chinese clothes. In cabarets and theatres of that time, dressing up as 'exotic' characters was popular. A few days later, on July 1 of 1869 , the same troupe of Chinese artists had their second appearance at the Zum Kaisersaal café in Scheidlitz (nowadays Siedlce - Gdańsk district) at the grand opening of the venue. ${ }^{31}$ No more information is available.

The wooden building was destroyed by a fire on July 1 of 1870 , and later rebuilt as Selonke's (Variété-Theater). The new brick building housed a show-consumption hall (Königssaal) with tables on the ground floor for 550 people and two floors of balconies. The balconies had boxes with armchairs for 460 spectators. There was also a pit for the orchestra and the stage. There was gas lighting. The theatre was inaugurated on December 23 of 1871, and had a light, entertaining repertoire. Vaudevilles and ballet performances were presented, with a large participation of traveling groups. ${ }^{32}$ Announcements on the page dedicated to Gdańsk entertainments give a comprehensive picture of the repertoire. In addition to the performances of the operetta and comedy prevailing in the program, there were invitations to the shows with the participation of 'exotic' artists.

In 1871, a concert took place in a café on the Motława River, which was announced in the press in the following way: "the famous Indian, Bamba Hugorillo, will appear in Cafe d'Angleterre tomorrow, January 31, for the first time." ${ }^{33}$

Wilhelm Theatre (Wilhelm-Theater) - under this name from April 1877 - replaced the former Selonke-Theater at Langgarten 31A (Długie Ogrody, Long Gardens Street). Refreshments were served at restaurant tables during the performances on the ground floor. The entertainment theatre hosted travelling troupes. It housed a light popular repertoire, in which chamber operas, comedies, vaudevilles and ballet performances dominated the program. From 1890-1920, ${ }^{34}$ the owner was the brother of the previous owner, Hugo Meyer and from the years 1920-1933, Paul Bansmann succeeded Meyer. Artistic management was carried out by individuals from the theatre and that of the music industry. In addition to the permanent band, many artists and troupes from outside Gdańsk performed on stage. The reading of press advertisements proves that the New Year's and carnival balls were also organized in the theatre halls.

30 Danziger Zeitung, 1869 no 5524 (June 27):4; Danziger Dampfboot, 1869 no 148 (June 29):2.

31 Danziger Zeitung, 1869 no 5452 (May 15):4.

32 Financial difficulties associated with the repayment of loans taken for construction forced the owner in April of 1877 to lease the theater to Otto Präger, who changed its name to Wilhelm-Theater.

33 Danziger Zeitung, 1871 no 6505 (Jan 30):4.

34 Due to the purchase of a part of the garden estate in December 1878 by the military authorities for the construction of the barracks at Herrengarten (Sadowa, Orchard Street), the activity was limited to the theatre building. 
This place was not only known from the theatre repertoire but also from other events. Here, on October 20 of 1896, the first cinema show in Gdańsk took place. The following screenings were presented: scenes from a Parisian street, a bicycle and cabriolet ride, and a carriage ride. From December 1 to December 16 of 1907, the stage of the theatre was the place of the international boxing tournament. Other commercial events were also held here (including boxing and wrestling fights as well as fashion shows). ${ }^{35}$

In the repertoires of the Wilhelm Theatre from 1907, we find, among others, the plays entitled: Ex-Kaiserin de Sahara and Theater Beduinen Gefolge. ${ }^{36}$ Later, in the fall, we find plays entitled: A trip to Coontown, 16 Neger Plantageleuten Theater ${ }^{37}$ and 16 Negerinnen und 16 Neger, ${ }^{38}$ and even later, the play entitled Die Wilden Frauen.$^{39}$ Having no coverage of these performances, I am unable to determine whether there were real Bedouins, Africans or answer the question of who played the wild women. However, even if these characters were partly played by white actors - which makes a difference - the titles of the performances themselves encouraged viewers by creating attractions through exotics.

During World War I, the theatre continued its activity, adapting the repertoire to the current war situation in Germany, often, especially in the beginning of the war, replacing entertainment programs with solemn or dignified performances. A similar climate change can be observed in the Gdańsk press. The number of obituaries of Gdańsk inhabitants killed in the front lines grew considerably. ${ }^{40}$

From spring 1920, Paul Bansmann, retained the old name of the venue but changed the form of performances for the operetta. The growing popularity of the cinema and the return to light entertainment resulted in the need for modernization. On September 2 of 1930, modernized building combining the cinema room with the variety scene was opened under the name of Scala derived from the famous local in Berlin. On the morning of June 7 of 1933, the fire completely destroyed the entire building, which was never rebuilt. In this way, the theatre ended its activity. ${ }^{41}$

Another important place in the entertainment landscape was the Tivoli Theatre (TivoliTheater), a summer entertainment theatre. It was opened on June 15 of 1849, in a wooden pavilion in the already operating Carl Gottlieb Schröder restaurant and café complex at Am Olivaer Tor 8 (Kosynierów Gdyńskich Street). The restaurant, serving its clients since 1819 , was known for concerts of chamber orchestra as well as soloists. Concert activities also continued after the opening of the summer theatre. The performances of the orchestra appealing to the Viennese designs of Johann Strauss were very popular.

The theatre program offered light, popular one- or several-act comedies and vaudevilles. Among others, on July 5 of 1849, the comedy by Carl Blum Ich bleibe ledig was staged. The theatre season was closed at the end of September in 1849. One or two premieres were performed on a weekly basis. In 1850, after the owner's death, the family took over the management of the premises, continuing their concert and theatre

\footnotetext{
35 https://www.gedanopedia.pl/gdansk/?title=D\%C5\%81UGIE_OGRODY (accessed March 11, 2019).

36 Danziger Zeitung, 1907 (Aug 31).

37 Danziger Zeitung, 1907 (Oct 16).

38 Danziger Zeitung, 1907 (Oct 24); Danziger Neueste Nachrichten, 1907 (Oct 15).

39 Danziger Zeitung, 1907 (Oct 29); Danziger Neueste Nachrichten, 1907 (Oct 26; Oct 28).

40 In 1915, a part of the facility was transformed into a hospital for Russian prisoners of war from the Przeróbka camp.

${ }^{41}$ https://www.gedanopedia.pl/gdansk/?title=D\%C5\%81UGIE_OGRODY (accessed March 11, 2019).
} 
activities. During the 1852 season, theatrical activity was suspended. It was resumed on July 1, 1883, with one performance. Further activity was discontinued; likely due to financial reasons.

During the years $1853-1855$, there were some summer concerts and performances by traveling troupes (for example, on August 5 of 1855 and on August 12 of 1855, the acrobatic and mimic group from Vienna) in the theatre halls. On October 3 of 1855, the owners of the theatres announced their willingness to sell it. However, they did not find buyers and the theatre ceased to operate. The restaurant was taken up by the son of Carl G. Schröder, Eduard. After his death in 1873, the restaurant was sold to the owner of the Stern Hotel and the restaurant at Targ Sienny (Hay Market) 4, Carl Ludwig Reddig (1817-1875). ${ }^{42}$

Other addresses and names of the premises were also mentioned in the press advertisements, among them is the entertainment garden called Freundschaftlichen Garten (Freundlicher Garten). It was a stage hall on Nowe Ogrody (New Gardens) Street. There were outdoor shows if the weather was favorable. They were held indoors if it rained. In 1898, Miss Fatima performed at Freundschaftlicher Garten ${ }^{43}$ She was advertised as the best athlete in Europe. It cannot be determined what nationality and origin this individual was.

Another venue of entertainment mentioned in the advertisement, was the zoological garden (Zoologischer Garten) located in a park in Wrzeszcz (nowadays Park Kuźniczki). It was where the performance of the Swahili Karawane took place in $1894 .{ }^{44}$ It proved impossible to establish whether there was actually a zoo there. Nevertheless, ads encouraging viewers to come to the show used this term.

Before I proceed to the presentation of the shows themselves, I put forward the approach that sets the framework for the relationship between space and performances. As Setha Low and Denise Lawrence-Zuniga write, there is a relationship between humans and the environments they occupy (2003:13). According to Low and Lawrence-Zuniga: "humans 'write' in an enduring way their presence on their surroundings" (2003:13). By observing different types of performances, we can gauge how experience is embedded in place and how space holds memories that implicate people and events.

In contrast to cathedrals, churches, large edifices or monuments of metropolitan architecture in general, buildings of small theatres have not survived. The first wooden buildings did not stand the test of time (today they would be more than 150 years old), the ones of brick erected later did not survive World War II. In a sense, they were light and impermanent, as the kind of art which was performed there.

Encounters with 'exotic others' took place in the public space of the city. They primarily took place in the city center, however, not in its very center, rather in the outskirts of the Old Town, in designated places. Symbolically, contact with the 'other' was in some way controlled, both by place and time (St. Dominic's Day). The meeting space with the 'exotic' outsider was also served by a defined circus and theatre space in which the exoticism of the actors was heightened by their performances of acrobatics, juggling in the circus, or various forms of art in theatres. Yet, from these places, flowed evocative power of unknown exoticism and fascination.

\footnotetext{
42 https://www.gedanopedia.pl/gdansk/?title=TEATR_TIVOLI (accessed March 11, 2019).

43 Danziger Zeitung, 1898 (Sept 23).

44 I owe pinpointing the location of these performances to Mr. Jerzy Michalak.
} 
The circus did not have a permanent place in Gdańsk in the sense of the building, as was the case in Warsaw (on Ordynacka Street) or in Wrocław (on Luisenplatz, nowadays Rozjezdny Square). It put up its tents even further outside the city, or rather near the city gates, or used the space in theatres (in the case of smaller groups). The theatres had their own glory days, which resulted in theatre advertisements, posters, and press reports.

Writing about Vienna, Robert Rotenberg observes that urban spaces represent changing relations of power and ideology. Urban planning for transforming urban landscapes served political and fiscal interests. The city was a site for the production of value both symbolic and financial. Parts of the city long ignored and neglected often became attractive targets for these projects. They represent the battle between the ideologies of absolutism/tradition and liberalism (ROTENBERG 1995:135). New districts were built with grandeur thanks to going beyond the former city walls. The areas of light entertainment in Gdańsk described here were located just outside the streets of the Old Town.

The majority of repertoire included concerts of classic music, and military concerts. Ethnic 'others' were smaller attractions. As displayed above, certain shows appeared in Gdańsk earlier than 1874 when a new model of presenting ethnic 'others' was introduced by Carl Hagenbeck. Data listed in the article reveals that ethnic performances were both presented in the open space of the St. Dominik's Fairs, and in closed stages of variété or cafés around the city center.

\section{EXOTIC SHOWS IN GDAŃSK}

The quoted data shows that interest in non-European places existed for a long period of time, and found new expressions from the 1860s onwards. I am aware that the interest in non-European cultures in Gdańsk as a shopping center is older, but I would like to emphasize that the data presented here come only from the press, so they are limited in time. The extensive review of press materials from 1860-1914 (mainly pieces published by Danziger Zeitung, Danziger Courier and Danziger Neueste Nachrichten) shows that three presentations of 'exotic' people took place in Gdańsk. It seems to me that there were no other shows of this type, although as we shall see later, encounters with 'others' took place.

The first of the demonstrations took place between August 3 and 17, 1890, when the "Black African (Negro) Wakamba caravan" appeared at the St. Dominic's Fair ${ }^{45}$ (Wakamba Neger Karawane). ${ }^{46}$ The shows took place in Targ Sienny (Hay Market). The spectacle was called a "Caravan of East African Negroes" [an original term] (der Ostafrikanischen Wakamba Neger Karawane). Later, the term "Wakamba Warriors' Caravan" (Wakamba Krieger Karawane) was added. The group consisted of fourteen people and arrived, led by the commander of Mitu. Africans were portrayed as dangerous opponents of the British colonial power, and in the then press in Gdańsk, the entire event was described:

"Fighting under the banner of their main Mitu leader, they were dangerous enemies of

Commissar of the Reich Major Mittmann. Stanley's travelers also appear in their stories and

\footnotetext{
45 The "Wakamba Negro Warrior Caravan" appeared in Munich in 1893 (DreesbaCh 2005:300).

46 Danziger Zeitung, 1890 (Aug 3):4.
} 
performances, dr. Peters and Emin Pasha, on the background of their barbarous messages, present the peculiarities of their struggle, their fantastically wild dances, and the stories of secret prisoners. ${ }^{\prime 47}$

It follows that the group not only presented its customs or folklore, but also enacted historical scenes. Nowadays we would call it reconstructions of meetings of famous travelers with natives and/or battles. I was unable to determine the name of the group's impresario. Nevertheless, it is plausible that the scenario was written by the impresario of the troupe who was familiarized with the interests of the public of German cities. ${ }^{48}$

The Wakamba tribe originates from eastern Africa. They were combative peoples, and in the period of the British colonies Wakamba were considered to be the premier martial race and sharp-shooters of Africa. ${ }^{49}$ The Kamba themselves appeared to embrace this label by enlisting in the colonial army in large numbers. They were included in the category of indigenous troops (askari), serving both in the British army, and in the French, German and Italian armies.

Three years later, between August 31 and September 11 of 1893, another caravan of Africans appeared in Gdańsk. In the press, they were presented as a Swahili caravan (Suaheli Karawane). ${ }^{50}$ Group members came from the east coast of Africa. In the Gutenberg Encyclopedia published in 1929-1938, under the entry 'Swahili', we find information about 'hybrids' of Arabs with 'blacks' from the shores of former German East Africa and neighboring islands dealing in the trade and service of caravans. ${ }^{51}$

According to the press release, their show took place in Freundschafticher Garten, and later in the Wilhelm Theatre.

"Yesterday night a caravan of Suahili came to Gdańsk from Tczew to present a thrilling
performance in the Freundschaftlichen Garten. The troupe consists of seven marriages and
two children, and one representative of the Singhalese tribe. Everyone is very well built,
especially some women are characterized by grace. Their teeth are strong, beautifully shaped
and dazzlingly white. The foreheads are more regular than other blacks, the lips are not so
prominent ... and woolly hair. Their skin color is yellow-brown and turns into black, Swahili
are healthy, good-natured and obedient. Their equipment is mainly used for the production of
cotton. In war dances, they wear ornaments from feathers and shells, and the dances are fiery

47 Danziger Zeitung, 1890 (Aug 3):4.

48 Anne Dreesbach cites data from which it appears that in 26 years (1874-1900) 150 groups visited Germany, in the next 15 years (from 1900 to 1914) 150 exotic groups, and later (until 1930) still 100 groups (DrEesBaCH 2005:111). This data proves the phenomenon described here was extremely popular in Germany.

49 Wakamba serving in the King's African Rifles (the KAR, Britain's East African colonial army) as loyal "soldiers of the Queen" during the Mau Mau Emergency. In the early 1950s the Kamba were deemed a hardy, virile, courageous, and "mechanically-minded tribe". Considered by many officers to be the "best [soldierly] material in Africa", the Kamba supplied the KAR with askaris (soldiers) (PARSONS 1999).

50 Danziger Zeitung, 1893 (Aug 8); 1893 (Sept 1):2; 1893 (Sept 4):4; Danziger Courier, 1893 (issue from Sept 2 to Sept 10).

51 Gutenberg Encyclopedia 1929-1938, vol. 16:(252). 
and wild, and the music is made of drums with bells. If the weather is good, the caravan Swahili will perform in the garden, in bad weather the performances will take place in the hall. ${ }^{, 52}$

In another press coverage of the performance entitled East Africa in Gdańsk, we read:

\begin{abstract}
"Today we had the opportunity to see the Swahili caravan for the first time. The troupe, which consists of about 16 members, has really beautiful characters; in particular, the white teeth of each newcomer are impressive. The show, according to today's entrepreneur's idea, was unfortunately weak. We are used to watching soldiers in the Freundschaftlichen Garten rooms, we do not advise our fellow citizens to enrich their knowledge in this way." ${ }^{33}$
\end{abstract}

Short descriptions of the shows fit into the classic, stereotypical representations of 'exotic' tribes in accordance with the form and tradition of that time and the iconography of the savages - "nudity, spears, decorative feathers and animated dances" (GRIFFITHS 2002: XIX). These peoples were often represented as "stuck in the evolutionary past". Other "scientific" shows were created for propagating racial theories that "skin color changes with latitude" (DEMSKi 2018:205). On the basis of the obtained materials that have been presented in this paper, it seems that within the atmosphere of entertainment, the area of ethnic shows prevailed in Gdańsk.

A few days later, a performance was mentioned where a child was delivered by one of the caravan members. This event caused some confusion among the midwives. At least to a certain degree, it also reflected the attitude of the average inhabitants of the city to exotic visitors.

"On Saturday afternoon, the Suahili caravan grew. One of the women gave birth to a small boy named 'Danzig'. Many midwives refused to serve a black woman. Finally, Mrs. W. from Scheidlitz (district of Gdańsk called Siedlce) managed to help her. This event brought great joy to the members of the caravan." 54

It is worth mentioning that from the previous findings it appears that the Swahili caravan previously appeared in the same year (June 4-6, 1893) in Poznan and in Leipzig (Deutsch-Ost Afrika Suaheli Karawane - June 27, 1893). In the Poznań press, the performance was announced as a Swahili concert or a Swahili caravan (DEMSKI 2019). Only advertisements have survived from Poznań, advising that the show will take place in the recreation part of the zoological garden. A lack of descriptions of the performances in Poznań makes it impossible to compare shows in both cities. The performances of the Swahili's should be treated as demonstrations of representatives of the new colonies (neues Landesmann), e.g. German East Africa (1885-1919, now Tanzania and Zanzibar). A comparison of the dates of the stay of the Swahili Africans in Poznań (June 4-6), Leipzig (June 27) and Gdańsk (Augut 31 - September 11) indicates that the troupe had two months between their performances; the question remains where they were giving performances during this period.

\footnotetext{
52 Danziger Zeitung, 1893 (Sept 1).

53 Danziger Courier, 1893 (Sept 2).

54 Danziger Zeitung, 1893 (Sept 4).
} 
The last known demonstration of 'exotic' peoples of this type from Africa took place in 1894. The newcomers also took part in the St. Dominic's Fair from July 31 to August $7 .{ }^{55}$ The press presented them as a "caravan of Negroes" (Neger Karawane). One of the announcements advertised their show in the 'zoological garden', located in the Kuźniczki Park in Wrzeszcz.

\begin{abstract}
"During the St. Dominic's Fair, in addition to other 'specialties' and attractions, a spectacle was made by the caravan of 20 Nanna Krou residents who will show themselves in their native performances. They will present war dances, fighting with spears, and sing religious songs. Negroes from the West African coast of paprika have chocolate brown skin, wear leopard clothes, chains and kauri shells and feather decorations. Incidentally, among these people is the son of an African king." ${ }^{56}$
\end{abstract}

Here is the second short report from the St. Dominic's Fair, in which the author gives a more detailed account of their ethnic background. He presents them as the Wakamba tribe from East Africa, as well as their territories and traditions.

\begin{abstract}
"The presentation of Mr. Urbach's Negers Wakamba was a great attraction. Since, according to the commentator, they did nothing wrong either to Wißmann or Stanley or Emin, because Wakamba people live in the English zone of interest, between the lake district and Mombasa, where none of these researchers ever reached, they are thus very interesting people. They belong to the Bantu tribes and are peaceful tribes engaged in farming and breeding cattle. Their combative neighbors, specifically the Maasai and Galla, immediately chase them away, so that they undergo very rapid anthropological decomposition. From their brothers, the Maasai, they took over their spears and shields from Galla, and borrowed some of their costumes. Their shows, which are quite successfully staged, were performed in a tastefully decorated room. ${ }^{57}$
\end{abstract}

The same group also performed in Torun (June 8 of 1894). The Plac Pod Bydgoską Bramą (Place at the Bydgoszcz Gate, Bromberger Thorplatz) was the place of not only this performance, but traditionally the place of exotic animal shows ${ }^{58}$ in Torun..$^{59}$

The group is presented as Neger Karawane, but more detailed information from a press release allows us to determine the details of their origin. They come from the west

55 Danziger Zeitung, 1894 (Aug 3; Aug 4); Danziger Courier, 1894 (Aug 2; Aug 4; Aug 5).

56 Danziger Zeitung, 1894 (Aug 4).

57 Danziger Zeitung, 1894 (July 8).

58 As an example: Thorner Presse, 1896 (Sept 19); 1899 (May 26).

59 "On Sunday, we met a Negro caravan, which gave a special performance on Bromberg Thorplatze. It has already erected the tents. As we were told, the son of King Quenty Nimel was among them. The warrior tribe came from the Pepper Coast (West Africa) of the Nanna Krou residence. They had a gory battle with the German ship "Viktoria" crew. The settlement was set in fire. Negro warriors presented a life-like situation, turmoil, manners and customs, wild war dances, and fighting techniques from their exotic homeland. Again we have the opportunity to admire their weapon skills, as well as the agility of the movements of these powerful figures. Visiting the show was encouraged" Thorner Presse, 1894 (June 8). 
coast of Africa, the so-called Pepper Coast. ${ }^{60}$ In the case of Neger Karawane, the dates of performances in Torun (June 8 of 1894) and Gdańsk (August 4 of 1894) indicated that the troupe also had two months for shows in other cities. Two accounts from the show in Gdańsk render different tribal names. It cannot be determined whether we are talking about two different groups, or it is rather the press coverage that was used for general information. In any case, they represented a group of former indigenous soldiers (askari) in the British army service.

Two groups, Wakamba and Neger Karawane, performed in the St. Dominic's Fair, and the troupe Suaheli Karawane arrived at the end of the summer, that is after St. Dominic's Day. The question arises as to why in the period of the unusual popularity of Völkerschau in Germany so few shows of this type took place in Gdańsk. Perhaps there was no suitable place in the city, such as a large zoological garden like in Poznan or Wrocław. For this reason, a troupe of a few individuals came to Gdańsk (twenty people in the case of the last Neger Karawane). They were not displayed separately but as one of many attractions.

\section{FROM EXOTIC TYPES TO EXOTIC ACTORS}

At the same time, however, the presence of a large number of circuses and variety shows were visible in the city. In their repertoire, there were representatives of 'exotic' peoples. They did not perform in their 'natural' environment this time. Rather, they presented specific skills that would capture the attention of the audience. These skills were associated with the body in the most visible way, where virtuosity was combined with an unusual appearance. Thus, there was a direct transition from wide exotic performances to showing off the skills of human bodies.

The bodies were now exposed in a more pronounced manner, i.e. in place of previous groups recreating scenes from life in different worlds; shows presenting the individual skills of troupe members were showcased.

The aforementioned demonstrations of African caravans presented authentic tribal groups, displaying their military service in colonial armies. They performed in their traditional role, offering examples from their own traditions and culture, combining original traditions with the function of an indigenous askari soldier.

The circus was a new kind of attraction for the audience; namely a combination of physical (Somali looks), classic (of India) traits, as well as specific skills. In the new form, the 'exotic' was even more visible as something to offer. On the other hand, it reflected the fantasies of the local imagination. The process of relying on the characters and their skills (not only on the types, as it was before) can be observed. New forms gradually

60 The coast of Africa encompassing today's countries of Liberia. According to the Gutenberg encyclopedia, the Pepper Coast covered the areas of western Guinea; that is, from Sierra Leone to Liberia (including the Ivory Coast). The name comes from the fact that melegueta pepper (Aframomum melegueta) was sold there. It is difficult to determine where the caravan came from. Nimla is a place in the county of Margibi in Liberia, but whether it is the place of origin of this group, it is difficult to say. It seems that the place of origin did not belong to Liberia, because the state functioned under America-Liberian rule (1847-1980). The rebellions of local tribes broke out in 1850-1920. 
departed from merely ethnic features, though they remained as an additional feature of the character. On the stage, what was extraordinary and amazing was increasingly more important. Original figures from distant sides depicted in their own habitat were slowly losing their previous charm, becoming part of a known world. Then a new type of stage appeared, a figure that was part of the story being played. In the era of pure entertainment, new characters on the stage of light theatres did not have any connections with ethnic identity anymore.

One can observe the process of transformation of a few 'exotic' troupes wandering around Europe into stars on tour. From exotic shows, one can observe this trend in the case of Zulu, Sioux (Demski 2020 analyzing the sequence of ethnic shows in Poznań), Ashanti and Singhalese.$^{61}$ In the new format, what else mattered - not a group representing a culture or a tribe, but characters that stood out from the "others". It is a clear breakthrough and departure from old patterns.

The materials presented here are a reflection of what has been preserved in the local press. Summing up the performances of 'exotic shows', it can be noted that they were primarily located in the city center and well linked with other districts. The repertoire was dominated by the standards of the then operetta and vaudeville. Interest in exoticism was evidenced by the titles of plays and performances mentioned above. Certain ethnic characters remained, yet their function changed. As for the public, some signs referring to their stereotypes about the peoples were sufficient.

Thus, we can see the presence of specific attractions in the discussed parts of the city from the perspective of urban space. It is not the space itself, but the entertainment practices inscribed in it for years that cause the imagination of the residents to meet new things, attractions and exotics: let's see what's new this year, what repertoire, and maybe technical innovations will be displayed.

\section{CONCLUSIONS}

As mentioned at the beginning of the paper, I strove to analyze the forms of presenting the 'exotic' based on the example of the city of Gdańsk. The shows did not allow the urban audience to immerse themselves in the 'exotic' landscape, yet they enabled the public to view the 'exotic' on stage, in the broad sense of the word. We can observe the evolution of content within the culture of attractions, which was presented at the beginning, and what appeared with the passage of time. The St. Dominic's Fair itself was a great stage where newer and more fascinating attractions appeared. The fascinating 'wildness' of the caravan was a fragment of a kaleidoscope of attractions (stalls, goods, balloons, zeppelins, sweets, gymnasts, circuses, dwarfs, etc.).

There were venues offering panoramic images of the world which were different, as well as the time spent in the theatre. There were a bulk of fascinating wonders that were not known on a daily basis. Some of them existed merely in order to create visual pleasure.

By juxtaposing materials from Poznań and Gdańsk, it can be stated that the real interest in 'exotic others' took place when the city dwellers could see them for the first

${ }_{61}$ See Eric Ames discussion of Hagenbeck's entertainment empire: Ames 2009. 
time. As the shows became more numerous, and thus more popular, fascination with the subject ended and their image, formerly abstract and distant, became stereotypical (also due to physical interaction). Interest in the 'exotics' changed to something else, such as technology, new inventions, and cinema.

It should be emphasized that the shows presented above are the opposite of encountering 'others' in their natural environment - which was not completely unknown to a small group of Gdańsk residents ${ }^{62}$ - but realizes the need to observe an 'exotic' other as such, regardless of the context. The one-way perspective was common. The way we perceive is under control, which Dominika Czarnecka showed in the context of women in Dahomey shows. They were constructed as a view (CZARNECKA 2020). However, if we leave the urban space, then we can think about where there were 'spaces for encounters with strangers'. Control takes place both spatially and during events. Foremost, performing space was meant for such encounters.

The claim of Setha Low and Denise Lawrence-Zuniga that "humans 'write' in an enduring way their presence on their surroundings" (2003:13) can be employed in the analysis of the two types of performances, namely those presented in the open space, such as the traditional St. Dominic's Fair (and park), and those organized in the light entertainment theatres, restaurants or café gardens. By observing different types of performances, we can speak to how experience is embedded in place and how the space in question holds memories that evoke people and events.

The structure of the performance required a specific place. In Gdańsk, shows of 'exotic' people with their animals did not exist. These type of groups and performances required adequate ground, preferably within the premises of zoological gardens. Performances presenting physical abilities, displaying guns or dancing required more space, hence the shows took place in the park, but also under the walls of the Old Town during the Dominican fairs. An example of this was Wakamba (1890) and Neger Karawane (1894). Press information focuses on the elements of the show. In an open space where there was no clear division into the stage and the audience, 'exotic' groups were treated as one of many in the variety of performances.

Descriptions of performances in the theater gardens, where the audience was sitting at tables busy with consumption, ${ }^{63}$ and the group of 'exotic' dancers, usually sparse in numbers, moved in a restricted space, make us assume that the reception of such performances could have been slightly different. What counted was the appearance of the character, music and movement without engaging in any detailed stories.

Ewa Partyga underlines the contrast between state theaters and garden scenes (2016:289-290). In my text, the St. Dominic's Fairs and variété theaters are included in the same category of places of unsophisticated pastimes. However, due to space - be it open or closed - and tradition, I try to highlight the emerging differences between them. Both represent similar values; yet they differ in form, the fair dating back to the previous period, while the theaters appeared along with the modernization of the city.

$\overline{62}$ See the materials of the Anthropological Society in Gdańsk (see footnote 16 for references), and examples of tourist destinations available for inhabitants of Gdańsk advertised in the Gdańsk press in 1904.

63 Ewa Partyga, in writing about Warsaw, mentions 'viewers behind barriers', that is, those who cannot afford even cheap chairs (2016:292). 
I would emphasize that the shows mentioned above were presented in two kinds of spaces; on the one hand, the open space of the St. Dominik's Fair and on the other, stage presentations in closed variété theatres and gardens, where the stage and the audience were separated. Access to the actors in the open space of the fair where stages were entangled with stalls and the public was not limited. This propels us to arrive at the conclusion that spatial dimensions reflected practices which were determined by the audience and the repertoire. Moreover, it suggests different types of power control related to the situation of the show. In an open space, such as the St. Dominik's Fair where no tickets were sold and one which was of a more commonplace character, the actors were intertwined to some extent. Thus, the barrier between actors and the audience was flexible, as the power relations were not rigidly marked. The concurrent existence of these shows, meant that in the urban landscape of the described times, the integration of different classes and various hierarchies of value was made possible within the area of the city space.

\section{REFERENCES CITED}

Ames Eric

2009 Carl Hagenbeck's Empire of Entertainment. Washington: University of Washington Press.

BARANiecKa-OlszewsKa, Kamila

2020 Buffalo Bill and Patriotism. The Criticism of the Wild West Shows in Polish Press in 1906. East Central Europe (forthcoming).

BisKUPSKI, Łukasz

2013 Miasto atrakcji. Narodziny kultury masowej na przełomie XIX i XX wieku [City of Attractions. The Birth of Mass Culture at the Turn of the Century]. Warszawa: Narodowe Centrum Kultury.

CASEY, Edward S.

1996 How to Get from Space to Place in a Fairly Short Stretch of Time. Phenomenological Prolegomena. In Feld, Stephen - BAsso, Keith H. (eds.) Senses of Place, 53-90. Santa Fe: School of American Research Press.

CIEŚLAK, Edmund

1969-1997 Historia Gdańska [The History of Gdańsk], vol. 1-5. Sopot: Wydawnictwo Lex.

CzARneCKa, Dominika

2018 “A w niedzielę szło się oglądać ludzi”. Pokazy etnograficzne we wrocławskim ogrodzie zoologicznym 1876-1930 [“And on Sunday We Went to Watch the People. Ethnographic Shows in the Wrocław Zoological Garden between 1876 and 1930]. Etnografia Polska 62(1-2):183-198.

2020 'Black' Female Bodies and the 'White' View. The Dahomey Amazon Show in Poland at the End of the Nineteenth Century. East Central Europe (forthcoming).

DAvis, Tracy C. (ed.)

2012 The Broadview Anthology of Nineteenth-Century British Performance. Peterborough: Ontario: Broadview Press. 
DEMsKi, Dagnosław

2018 „Spoglądając wstecz”. Wystawa szczepów z Doliny Nilu w Poznaniu, 1914 ["Looking Back". Poznań Exhibition of the Tribes of the Nile Valley, 1914]. Etnografia Polska 62(1-2):199-219.

2018a Azja w cudzych oczach. „Pokazy” ludów azjatyckich na ziemiach polskich na przełomie XIX i XX wieku [Asia in Foreign Eyes. Ethnographic Shows of Asian Peoples on Polish Lands in the Turn of the $20^{\text {th }}$ Century]. In BARANIECKAOlszewsKa, Kamila - KabzińsKA, Iwona - TANGAD Oyungerel (eds.) Lokalne $i$ globalne perspektywy azjanistyczne. Księga jubileuszowa dla Profesora Stawoja Szynkiewicza, 295-308. Warszawa: Wydawnictwo IAE PAN.

2020 Spaces of Modernity. Exotic Shows in Poznań, 1879-1928. East Central Europe (forthcoming).

DreEsBaCH, Anne

2005 Gezähmte Wilde: Die Zurschaustellung “exotischer" Menschen in Deutschland 1870-1940. Frankfurt-New York: Campus.

EDENSSOR, Tim

1998 Tourists at the Taj. Performance and Meaning at a Symbolic Site. LondonNew York: Routledge.

\section{FrITSCH, Gustav}

1872 Die Eingeborenen Suedafrikas. Atlas. Breslau.

GidDens, Anthony

2002 [1991] Nowoczesność $i$ tożsamość. „Ja” $i$ spoleczeństwo $w$ epoce późnej nowoczesności. [Modernity and Self-Identity. Self and Society in the Late Modern Age]. Warszawa: PWN.

2003 [1984] Stanowienie społeczeństwa. Zarys teorii strukturyzacji [The Constitution of Society. Outline of the Theory of Structuration]. Poznań: Zysk i S-ka.

2008 [1990] Konsekwencje nowoczesności [The Consequences of Modernity]. Kraków: Wydawnictwo Uniwersytetu Jagiellońskiego.

GLIŃSKI, Mirosław - KuKLIŃSKI, Jerzy

1998 Kronika Gdańska, 997-2000 [The Chronicle of Gdańsk, 997-2000], vol. 1-2. Gdańsk: Fundacja Rewaloryzacji Zabytków Gdańska; Wydział Promocji Miasta Urzędu Miejskiego w Gdańsku.

Griffiths, Alison

2002 Wondrous Difference: Cinema, Anthropology and Turn-of-the-Century Visual Culture. New York: Columbia UP.

GUTENBERG ENCYCLOPEDIA

1929-1938 Wielka ilustrowana encyklopedia powszechna [The Great Universal Illustrated Encyclopedia], vol. 1-22. Kraków: Wydawnictwo Gutenberga.

Hastrup, Kirsten

1998 A Place Apart. An Anthropological Study of the Icelandic World. Oxford: Clarendon Press.

INGOLD, Tim

2000 The Perception of the Environment. Essays on Livelihood, dwelling and Skill. London-New York: Routledge. 
Kirschenblatt-Gimblett, Barbara

1998 Destination Culture. Tourism, Museums, and Heritage. University of California Press, Berkeley.

KureK, Krzysztof - MeYer, Mateusz

2017 Spacery, koncerty i... „tubylcze wioski”. O (dwuznacznych) przyjemnościach oferowanych w ogrodzie restauracyjnym poznańskiego Zoo w XIX i na początku XX wieku [Walks, Concerts and... 'Tribal Villages'. On (Ambiguous) Amusements Offered by the Restaurant Garden in the Poznan Zoo at the Turn of the $20^{\text {th }}$ Century]. In Guderian-CzaplińsKa, Ewa - KuREK, Krzysztof (eds.) Teatralne przyjemności. Prace ofiarowane Profesor Elżbiecie Kalembie-Kasprzak, 45-59. Poznań: Wydawnictwo UAM.

Low, Setha M. - Lawrence-Zuniga, Denise

2003 The Anthropology of Space and Place: Locating Culture. London: WileyBlackwell.

OrŁowicz, Mieczysław

1928 Przewodnik po Gdańsku [Guide around Danzig]. Warszawa: Nakładem Polskiego Towarzystwa Krajoznawczego w Warszawie.

PARSONS, Timothy H.

1999 "Wakamba Warriors Are Soldiers of the Queen": The Evolution of the Kamba as a Martial Race, 1890-1970. Ethnohistory 46(4):671-701.

PARTYGa, EWA

2016 Wiek XIX. Przedstawienia [The Nineteenth Century. Spectacles]. Warszawa: Instytut teatralny - PIW.

RANKE, Johannes

2017 [1923] Der Mensch: Zweiter Band: Die heutigen und die vorgeschichtlichen Menschenrassen. Nikosia: TP Verone Publishing House Ltd.

RotenberG, Robert Louis

1995 Landscape and Power in Vienna. Baltimore: The Johns Hopkins University Press.

SALMi, Hannu

2010 Europa XIX wieku. Historia kulturowa [Nineteenth-Century Europe. A TUAN, Yi-Fu Cultural History]. Kraków: Wydawnictwo Uniwersytetu Jagiellońskiego.

1987 Przestrzeń $i$ miejsce [Space and Place. The Perspective of Experience]. Warszawa: PIW.

\section{ARCHIVAL SOURCES}

Gdańsk

Archiwum Państwowe [State Archive]

7.561: Anthropologischer Verein zu Danzig und andere naturforschende Gesellschaften Vereine 1875-1892.

7.562: Anthropologischer Verein zu Danzig und andere naturforschende

Gesellschaften Vereine 1892-1918. 
Dagnosław Demski serves as Associate Professor at the Institute of Archaeology and Ethnology of the Polish Academy of Sciences in Warsaw. His research interests include two broad areas of Central and Eastern European and South Asian studies. He focuses on ethnic studies, concepts of otherness in staging and visuality, visual anthropology and anthropology of the body. https://orcid.org/0000-0002-3977-0294 E-mail: d.demski2@gmail.com 